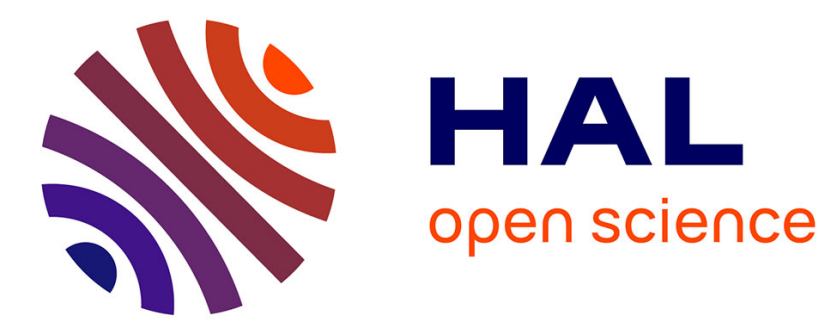

\title{
AN ACOUSTIC APPROACH TO MILLIMETER-WAVE LINEWIDTH SPECTROSCOPY
}

\author{
A. Di Lieto, G. Buffa, P. Minguzzi, O. Tarrini, M. Tonelli, M. Meucci
}

\section{To cite this version:}

A. Di Lieto, G. Buffa, P. Minguzzi, O. Tarrini, M. Tonelli, et al.. AN ACOUSTIC APPROACH TO MILLIMETER-WAVE LINEWIDTH SPECTROSCOPY. Journal de Physique Colloques, 1983, 44 (C6), pp.C6-547-C6-551. 10.1051/jphyscol:1983690 . jpa-00223249

\section{HAL Id: jpa-00223249 https://hal.science/jpa-00223249}

Submitted on 1 Jan 1983

HAL is a multi-disciplinary open access archive for the deposit and dissemination of scientific research documents, whether they are published or not. The documents may come from teaching and research institutions in France or abroad, or from public or private research centers.
L'archive ouverte pluridisciplinaire HAL, est destinée au dépôt et à la diffusion de documents scientifiques de niveau recherche, publiés ou non, émanant des établissements d'enseignement et de recherche français ou étrangers, des laboratoires publics ou privés. 


\title{
AN ACOUSTIC APPROACH TO MILLIMETER-WAVE LINEWIDTH SPECTROSCOPY
}

\author{
A. Di Lieto ${ }^{+*}$, G. Buffa ${ }^{+*}$, P. Minguzzi $i^{*}$, O. Tarrini ${ }^{+*}$, M. Tonelli $i^{+*}$ and \\ M. Meucci ${ }^{* *}+$ \\ - Scuola Normale Superiore, Pisa, Italy \\ * Dipartimento di Fisica dell'Università, Pisa, Italy \\ ** Istituto di Fisica delz'Universita, Siena, Italy
}

Résumé - On décrit un nouvel appareil expérimental pour la mesure de l'élargissement par collision des raies rotationnelles dans la région des ondes millimetriques. La cellule qui contient le gaz est un détecteur acoustique avec une grande sensibilité à basse pression. On compare les coefficientsd'élargis-

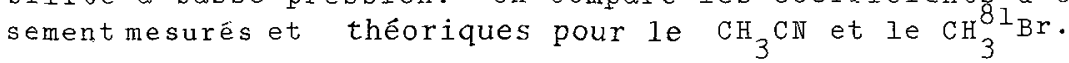

\begin{abstract}
We describe a novel experimental apparatus to measure the collision broadening of rotational lines in the millimeter-wave region. The sample cell is a small acoustic detector featuring high sensitivity at low pressure. We measured the broadening coefficients for $\mathrm{CH}_{3} \mathrm{CN}$ and $\mathrm{CH}_{3} 8 \mathrm{I}_{\mathrm{Br}}$ and we compared them with the theoretically estimated linewidths.
\end{abstract}

1. Introduction. - The application of the photoacoustic (PA) technique to the millimeter-wave spectroscopy of gases is rather uncommon $(1,2)$ and only in few cases the results are comparable or superior to those obtained in conventional spectrometers. The main reason for unsatisfactory performances is the use of acoustic cells not designed for low pressure operation. In this paper we show that an acoustic detector displaying good sensitivity at low pressure can enhance the advantages of the PA technique.

One of the main problems in conventional spectrometers is the troublesome effect of standing waves. In fact, in a waveguide cell, the power reaching the crystal detector strongly depends on the $r$ adiation frequency because of unwanted reflections from microwave com.ponents. As a consequence there are distortions and shifts in the observed lineshapes which spoil the measurement accuracy. In the cm- waves the errors can be reduced by a careful design of the waveguide circuit (3), but this approach is increasingly impervious when the wavelength is decreased to the mm-wave range. The PA detection allows the direct observation of the shape of absorption lines free from background signals; virtually no standing wave is generated at the detector and the power varies smoothly with the radiation frequency.

A second critical point in linewidth spectroscopy is the tight control of the sample parameters, such as purity, pressure and

+also Gruppo Nazionale Struttura della Materia 
temperature. Conventional spectrometers are sometimes cumbersome since typical absorption cells are tens of meters long: in such a situation to keep homogeneous and stable gas parameters may be a difficult task. The PA tecnique allows a very small volume of the sample cell (a few centimeters of absorption path can yield a high sensitivity) so that it is much easier to keep the experiment under control.

The purpose of this paper is to describe an apparatus designed for the study of pressure broadening of absorption lines in the $75 \mathrm{GHz}$ region and to present results obtained for two symetric-top molecules.

2. - Experimental details. - The schematic diagram of the experimental apparatus is shown in Fig. 1. The radiation source is a band-Eklystron which is phase-locked to a crystal oscillator. The servo loop has been designed so that the klystron frequency can be swept and modulated while keeping a high spectral purity: it contains a programmable synthesizer controlled by a microcomputer which also manages the data acquisition.

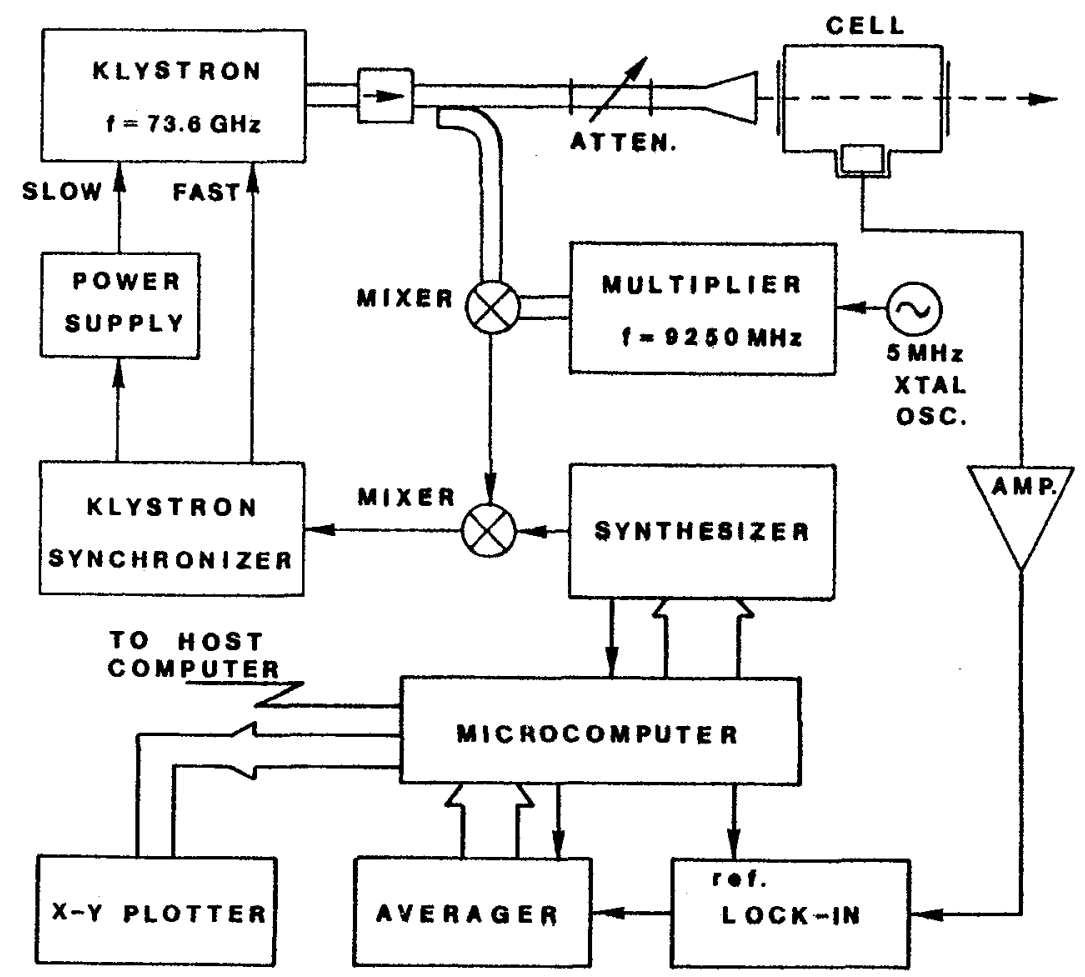

Fig.1 : Experimental apparatus

The detector cell is not acoustically resonant, since we found that a small volume and a low modulation frequency give supexior performances at low pressure. The cell is machined out of an aluminium 
cube with $30 \mathrm{~mm}$ external dimensions and $12 \mathrm{~mm}$ bore. So the sample chamber is a cylinder of about $3.4 \mathrm{~cm}^{3}$; it is terminated by tefion windows and the vacuum tightness is ensured by 0 -rings. A commercial electret microphone is fitted into each of the four side walls and the electrical feedthroughs are glued to plastic plugs. The outputs of the microphones are preamplified and combined in a low noise suming amplifier. The cell works at ambient temperature and some care is used to isolate it from the mechanical vibrations of the floor and the table; however no caution is required against the environmental acoustical noise since at low pressure its effect is negligible. For an incident power of a few mwatts the minimum operating pressure is about 25 mTorr. The sample gas is slowly flown through the cell and the pressure is measured at input and output by two capacitance manometers; measurements are taken at different pressures in the range 25-500 mTorr.

The klystron is frequency modulated and slowly swept through the gas absorption region; a typical modulation fxequency is $266 \mathrm{~Hz}$ but this value is by no means critical. We preferred frequency modulation to amplitude modulation, since for narrow gas lines this method is of great help in suppressing coherent background from absorption in the cell windows. As a further advantage, in the mm-wave range, frequency modulation is technically easier than amplitude modulation.

The signal from the microphone preamplifier is processed by a lock-in detector and recorded on a digital averager as a function of the klystron frequency (Fig. 2)

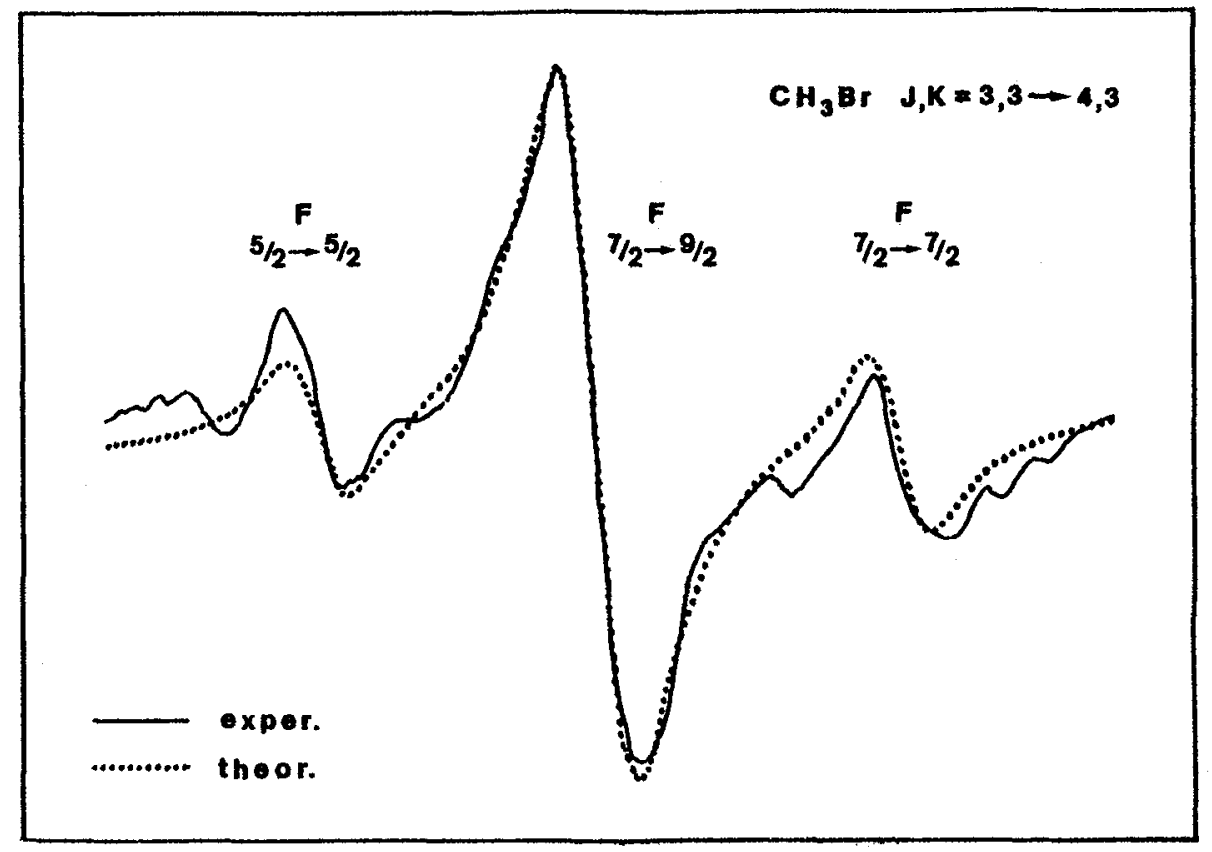

Fig. 2: $\mathrm{PA}$ spectrum of $\mathrm{CH}_{3} \mathrm{Br}$ in a $40 \mathrm{MHz}$ range near $76.3 \mathrm{GHz}$. The sample pressure is about 100 mTorr. 
Each curve is analyzed in a nonlinear least-squares fitting program to obtain the linewidth parameters. The computer code takes into account possible distortion of the lines caused by modulation and saturation. In fact one of the difficulties of the experiment is that the PA signal is roughly proportional to the incident power while the sensitivity decreases rapidly at low pressure: so some saturation may be necessary to achieve an acceptable signal-to-noise ratio.

The estimated width of the lines displays a linear dependence on the pressure; the slope of the linewiath as a function of the pressure yields directly the collision-broadening coefficient.

3. Results. - We have studied the two symmetric top molecules $\mathrm{CH}_{3} \mathrm{CN}$ and CH $8 I_{B r}$ Theoretical estimates of the broadening coefficients can be obtained by the Anderson theory: due to the approximations introduced in this theory the agreement with experiment is expected within 10-20\%. The theory reproduces better the trend in $k$ than the absolute value of the broadening coefficients; this is confirmed by our measurements on the spectrum of $\mathrm{CH}_{3} \mathrm{CN}$.

\begin{tabular}{|c|c|c|c|c|c|c|c|}
\hline \multicolumn{2}{|c|}{$\mathrm{CH}_{3} \mathrm{CN}$} & $J=3-4$ & & \multicolumn{2}{|c|}{$J=3-4, \quad K=3$} & \multirow[b]{2}{*}{ Exper. } \\
\hline K & Theory & Exper. & $2 F$ & $2 \mathrm{~F}^{\prime}$ & Theory (a) & Theory (b) & \\
\hline 0 & 65.7 & $53.9(2.9)$ & 5 & 5 & 11.6 & 18.6 & $13.3(0.6)$ \\
\hline 1 & 64.4 & $54.8(2.2)$ & \multirow[t]{2}{*}{7} & \multirow[t]{2}{*}{7} & \multirow[t]{2}{*}{11.6} & \multirow[t]{2}{*}{18.5} & \multirow[t]{2}{*}{$13.3(0.6)$} \\
\hline 2 & 60.1 & $50.7(1.3)$ & & & & & \\
\hline 3 & 50.5 & $42.6(1.0)$ & 7 & 9 & 11.6 & 18.4 & $13.3(0.6)$ \\
\hline
\end{tabular}

Table I : Experimental and theoretical broadening coefficients (MHz/Torr.) For the case of $\mathrm{CH}_{3} \mathrm{Br}$ we report the theoretical estimates for both unresolved ( ${ }^{3}$ ) and resolved (b) hyperfine transitions.

The spectrum of $\mathrm{CH}_{3} \mathrm{Br}$ exhibits a large hyperfine structure, so that it is possible to compare the experimental results to the theoreti cal estimates in the case of a resolved hyperfine structure. Theory leads to two different broadening coefficients in the case of resolved and unresolved hyperfine components. It is worth noting that, if the resolved hyperfine theoretical value is used, the theory-to-experiment width ratio is nearly the same for the two molecules $\mathrm{CH}_{3} \mathrm{CN}$ and $\mathrm{CH}_{3} \mathrm{Br}_{\mathrm{B}}$ gxperimental results for $\mathrm{CH}_{3} 8 \mathrm{Br}$ are however only preliminary estimates. Table I reports measured and calculated broadening coeficierts. The experimental results are in reasonable agreement with the existing broadening data obtained by conventional techniques $(4,5)$.

It may arise the question whether the width observed by the PA technique has the same physical meaning as that measured in conventional spectrometry. The satisfactory agreement between theory and experiment suggests that the two methods are actually aimed at the same physical observable. An even closer agreement has been recently 
reported for lineshift data obtained by Krupnov and coworkers using an acoustic detector in the submillimeter region (6) and the corresponding computations by the theory $(7)$.

4. Conclusion - The results we present show that our apparatus compares well with traditional spectrometers. The use of a PA aetector has permitted a simpler experimental set-up, a careful control of operating parameters and a more immediate acquisition and elaboration of data.

\section{References}

(1) A.P.KRUPNOV in "Modern Aspect of Microwave Spectroscopy", G.W.Chantry ed., Academic Press (London;1979)

(2) G.BUFFA, A.DI LIETO, P.MINGUZZI, M.TONELLI: Int.J. of Infrared and Millimeter Waves, 2 (1981) 559

(3) G.BUFFA, M.MARTINELLI; O.TARRINI, C.UMETON; J.Phys. B: Atom.Molec. Phys. 12 (1979) 743

(4) J.A.ROBERTS, T.K.TUNG, C.C.IIN; J.Chem.Phys. 48 (1968) 4046

(5) W.A.WENSINK, C.NOORMAN, H.A.DIJKERMAN; J.Phys. B: Atom.Molec. Phys. 13 (1980) 4007

(6) S.P.BELOV, U.P.KAZAROV, A.F.KRUPNOV,V.N.MARKOV, A.A.MEL'NIKOV, V.A.SKVORTSOV, M.YU.TRET'YAKOV; J.Molec. Spectros. 94 (1982) 264.

(7) G.BUFFA, O.TARRINI; J. Molec. Spectros., in press. 